\title{
Esophagus and Esophagogastric Junction Cancer TNM Finding v8
}

National Cancer Institute

\section{Source}

National Cancer Institute. Esophagus and Esophagogastric Junction Cancer TNM Finding v8. NCI Thesaurus. Code C133365.

A finding about one or more characteristics of esophagus and esophagogastric junction cancer, following the rules of the TNM AJCC v8 classification system. This staging system applies to carcinomas including squamous cell carcinoma, adenocarcinoma, adenosquamous carcinoma, undifferentiated carcinoma, neuroendocrine cancers, and adenocarcinoma with neuroendocrine features. Sarcomas, nonepithelial cancers, and gastrointestinal stromal tumors are not staged using this staging system. (from AJCC 8th Ed.) 